\title{
A Comparison between Several Commercial Polymer Hollow Fiber Membranes for Gas Separation
}

\author{
Xiao Yuan Chen ${ }^{1,2,}$, Serge Kaliaguine ${ }^{1}$ and Denis Rodrigue ${ }^{1}$ \\ ${ }^{1}$ Department of Chemical Engineering, Université Laval, Quebec City, QC, G1V OA6, Canada \\ ${ }^{2}$ Centre National en Électrochimie et en Technologies Environnementales, Collège de Shawinigan, \\ Shawinigan, QC, G9N 6V8, Canada
}

\begin{abstract}
Polyethersulfone (PES), polyetherimide (Ultem ${ }^{\circledR} 1000$ ), and polyimide (Matrimid ${ }^{\circledR}$ 5218) are common commercial polymers used to produce hollow fiber membranes for different gas separation applications. In this work, asymmetric hollow fiber membranes were prepared using these polymers by a phase inversion technique. The effects of spinning parameters (composition of the dope and bore solution, bore flow rate, air gap distance, temperature of the spinneret and coagulation bath, as well as take-up speed) on the membrane structure and gas permeation properties were investigated. The membrane separation performances were characterized by measuring their gas permeation properties (permeance and selectivity) for different gases $\left(\mathrm{H}_{2}, \mathrm{CO}_{2}, \mathrm{O}_{2}, \mathrm{~N}_{2}\right.$, and $\left.\mathrm{CH}_{4}\right)$ and by their cross-sectional morphology using scanning electron microscopy (SEM). The relationships between the gas separation performance of the hollow fibers and the intrinsic gas properties of the dense flat membranes made of the same materials were also studied. A comparison between the average apparent skin layer thickness calculated from $\mathrm{O}_{2}$ permeability/permeance, and the results based on SEM images was made and good agreement was obtained between both results.
\end{abstract}

Keywords: Polymer, membrane, gas separation, permeability, permeance, selectivity.

\section{INTRODUCTION}

Gas separation based on membrane technology plays a major role in the purification of gas because of its high efficiency, low power consumption, easy control, simple maintenance and low investment cost, compared to conventional separation processes such as cryogenic distillation, adsorption and absorption [1]. Different techniques can be used for gas separation according to their origin and intended use. A recent economic study comparing the estimated costs for five biogas purification technologies (chemical absorption, pressure washing, organic washing, adsorption and membrane separation) showed that membrane technology has several advantages. For example, it has the possibility to adjust the plant layout to local features like low electrical energy demand, low investment and operating costs [2]. The global market for membrane separation was valued at $\$ 19.0$ billion in 2012 and is expected to grow at an annual rate of $10.8 \%$ between 2013 and 2019, reaching a value of $\$ 39.2$ billion in 2019 [3]. This technology can be applied in several industrial sectors requiring gas purification units such as [4]:

1. Separation of the main component of air (nitrogen and oxygen, $\mathrm{O}_{2} / \mathrm{N}_{2}$ ),

2. Separation of hydrogen from a synthesis gas (syngas, $\mathrm{H}_{2} / \mathrm{CH}_{4}, \mathrm{H}_{2} / \mathrm{CO}_{2}$ ),

*Address correspondence to this author at the Department of Chemical Engineering, Université Laval, Quebec City, QC, G1V 0A6, Canada; Tel: 418-656-8368; E-mail: xiao-yuan.chen1@ulaval.ca
3. Recovery of hydrogen in ammonia plants $\left(\mathrm{H}_{2} / \mathrm{N}_{2}\right.$, $\mathrm{H}_{2} / \mathrm{CH}_{4}$ ),

4. Recovery of hydrogen in petroleum refining processes $\left(\mathrm{H}_{2} / \mathrm{CO}\right)$,

5. Concentration of methane from biogas $\left(\mathrm{CO}_{2} / \mathrm{CH}_{4}\right)$,

6. Purification of natural gas $\left(\mathrm{CO}_{2} / \mathrm{CH}_{4}\right)$,

7. Removal of the water vapor from natural gas and other gases $\left(\mathrm{H}_{2} \mathrm{O} / \mathrm{CH}_{4}\right)$,

8. $\mathrm{CO}_{2}$ capture $\left(\mathrm{CO}_{2} / \mathrm{N}_{2}\right)$,

9. Recovery of helium from rejected gas streams during natural gas processing $\left(\mathrm{He} / \mathrm{N}_{2}\right)$.

Gas separation membranes are generally made from organic and inorganic materials. Inorganic membranes include metals, ceramics, metal organic frameworks (MOF) or carbon molecular sieves (CMS), but most of the membranes today are organic made from polymers because they are cheaper, more pressure stable and easier to produce than inorganic or metal membranes [5].

Several families of polymers have been studied as membrane materials for gas separation. Some examples are polycarbonates (PC), cellulose acetate $(\mathrm{CA})$, polyethersulfone (PES), polyimides (PI), polyetherimide $(\mathrm{PEI})$, polypyrrolones and silicone rubber. Cellulosic membranes dominate the market 
because the material is less expensive than other polymers, covering $57 \%$ of the total market (2009). However, CA membranes have a very low selectivity in the separation of gas mixtures in relation to the permeability of pure gases due to the plasticizing effect of $\mathrm{CO}_{2}$ or heavy hydrocarbons in the gas mixture [6]. Silicone rubber membranes (for example PDMS) exhibit poor mechanical properties and low selectivities [7].

For gas purification at an industrial scale, a large membrane surface area is needed. Currently, three types of configurations are used for industrial applications: hollow fiber module, spiral wound and envelope. Compared with the other membrane configurations, hollow fibers provide higher surface area per unit volume (module) leading to higher separation capacity [4]. Actually, hollow fiber membrane modules have values on the order of 10000 $\mathrm{m}^{2} / \mathrm{m}^{3}$, which is significantly higher than spiral wound $\left(200-1000 \mathrm{~m}^{2} / \mathrm{m}^{3}\right)$ and envelope type $\left(30-500 \mathrm{~m}^{2} / \mathrm{m}^{3}\right)$ modules [4]. In addition, hollow fiber modules provide mechanical support and are easier to handle. The gas separation process is also simpler [8]. The membrane modules can be used for large or small scale in several industrial sectors. Therefore, hollow fiber modules are more commonly used for industrial applications.

Polyethersulfone (PES), polyetherimide (Ultem $^{\circledR}$ 1000 ), and polyimide (Matrimid ${ }^{\circledR}$ 5218) are common commercial polymers used to produce flat and hollow fiber membranes for different applications, especially for gas phase separation. For example, polyethersulfone (PES) hollow fiber membranes are prepared using alcohol (methanol, ethanol, 1-propanol, 1-butanol and 1-pentanol) [9] or water [10] as the nonsolvent additive, and $\mathrm{N}$-methyl-2-pyrrolidone (NMP) as the solvent. The group of Chung studied the effect of orientation relaxation and bore fluid chemistry on the morphology and performance of polyethersulfone hollow fibers for gas separation [11]. They also produced dual-layer hollow fiber membranes using different PES concentrations with an ultrathin denseselective layer of $40.7 \mathrm{~nm}$ for $\mathrm{O}_{2} / \mathrm{N}_{2}$ separation [12]. Kapantaidakis et al. used PES blends with polyimide Matrimid 5218 (PI) [13], Kusworo et al. [14] used the same hybrid material loaded with zeolite $4 \mathrm{~A}$, and Widjojo et al. [15] used PES-beta zeolite/PES- $\mathrm{Al}_{2} \mathrm{O}_{3}$ dual-layer mixed-matrix to make hollow fiber membranes for enhanced separation performance, or zeolite 4A treated with dynasylan ameo (DA) silane agent [16] hollow fiber membranes to improve the gas separation. Chen et al. [17] used diethyleneglycol (DG) as a non-solvent additive to increase the bulk and surface porosity, and coated multi-ultrathin layers of poly(ethyleneglycol) (PEG) to develop PES hollow fiber membranes for $\mathrm{CO}_{2} / \mathrm{N}_{2}$ separation.

Three grades of polyetherimide (PEI) are commercially available:Ultem ${ }^{\circledR} 1000$, Ultem ${ }^{\circledR} 1010$ and Extem $^{\circledR}$ XH1015. Wang et al. [18] prepared Ultem ${ }^{\circledR}$ 1000 hollow fibers and tested six gases: $\mathrm{N}_{2}, \mathrm{CH}_{4}, \mathrm{He}$, $\mathrm{O}_{2}, \mathrm{CO}_{2}$ and $\mathrm{H}_{2}$. Their results showed that $\mathrm{He} / \mathrm{N}_{2}$ selectivity can be as high as 90 . On the other hand, Ultem 1000 mixed with modified HSSZ-13 zeolite hollow fiber membranes were used for $\mathrm{O}_{2} / \mathrm{N}_{2}, \mathrm{He} / \mathrm{N}_{2}$, $\mathrm{CO}_{2} / \mathrm{CH}_{4}$ separations [19], while Ultem 1000 mixed with ZIF-80 was used for $\mathrm{CO}_{2} / \mathrm{N}_{2}$ separations [20]. Hollow fiber prepared from Ultem 1010 with polyethylene glycol (PEG) dissolved in NMP (solvent) as spinning dope and $0.2 \mathrm{wt} . \%$ poly(4-vinylpyridine) and $3 \mathrm{wt} \%$ silicone rubber was chosen as the selective layer material for coating the outside surface. These membranes were then used for $\mathrm{H}_{2} / \mathrm{N}_{2}, \mathrm{CO}_{2} / \mathrm{CH}_{4}, \mathrm{O}_{2} / \mathrm{N}_{2}$ separations [21]. Extem ${ }^{\circledR} \mathrm{XH} 1015$ polyetherimide hollow fibers were fabricated to study $\mathrm{O}_{2} / \mathrm{N}_{2}$ separation [22].

Among PES, PEI and Matrimid, Matrimid ${ }^{\circledR} 5218$ is currently the most studied one. Koros's group prepared Matrimid hollow fiber membranes for $\mathrm{O}_{2} / \mathrm{N}_{2}$ separation [23], which was also used for propylene/propane separation [24]. Then, some studies focused on the improvement of the separation properties of these membranes by blending with other polymers such as PES at different Matrimid/PES ratios (20/80, 50/50, 80/20) [25], as well as poly[2,20-(1,3-phenylene)-5,50bibenzimidazole] (PBI) (Matrimid/PBI of 25/75, 50/50, 75/25) [26] and polymers of intrinsic microporosity (PIM-1) (Matrimid/PIM-1 of 95/5, 90/10, 85/15) [27]. The group of Chung prepared dual-layer hollow fibers with neat Matrimid [28-29] or Matrimid/PBI (1:1) [30] as the outer layer material with PES or PES blended with Ultem 1000 as the inner layer material. The group of Chen focussed on the optimization of the spinning parameters. The $\mathrm{CO}_{2} / \mathrm{CH}_{4}$ separation factor (47) of the fibers exhibited higher selectivity than the intrinsic selectivity of the dense flat membranes (31-37) [31] and used $0-12 \%$ wt. poly(ethylene glycol)(PEG) or poly(ethylene oxide) (PEO)-polydimethylsiloxane (PDMS) PEO-PDMS block copolymers to improve the $\mathrm{CO}_{2} / \mathrm{N}_{2}$ gas separation performance [32]. Finally, the group of Koros developed nodular selective layers of Matrimid hollow fibers displaying much higher $\mathrm{CO}_{2} / \mathrm{N}_{2}$ selectivity as well as higher $\mathrm{CO}_{2}$ permeance [33]. 
The main objective of this work is to compare three asymmetric hollow fiber membranes working under optimized conditions by measuring their separation performances for different gases $\left(\mathrm{H}_{2}, \mathrm{CO}_{2}, \mathrm{O}_{2}, \mathrm{~N}_{2}\right.$, and $\mathrm{CH}_{4}$ ). Three commercial polymers (polyethersulfone, polyetherimide, and polyimide) were selected to produce the membranes using the same method. From the samples obtained, the relationships between the gas separation performance of the hollow fibers and the intrinsic gas properties of the dense flat membranes are also discussed. Finally, the gas transport properties of a single fiber and modules (up to 20 fibers) are compared.

\section{BACKGROUND AND THEORY}

The solution-diffusion model is used to explain the gas transport through all polymer films, as well as hollow fibers. Therefore, the permeability coefficient $(P)$ is determined by [34]:

$$
N=P\left(\frac{\Delta p}{l}\right)
$$

where $N$ is the permeation flux, $\Delta p$ is the pressure difference across the membrane, and $l$ is the membrane thickness. It is assumed that a single gas goes through the membrane of constant thickness placed between two zones: upstream $\left(p_{2}\right)$ and downstream $\left(p_{1}<p_{2}\right)$. The permeance $Q$ is defined as the ratio of permeability over thickness as [35]:

$Q=\frac{P}{l}=\frac{N}{\Delta p}$

Ideal selectivities of flat $\left(\alpha_{f}\right)$ and hollow fiber $\left(\alpha_{H}\right)$ membranes are defined as [34, 35]:

$$
\begin{aligned}
& \alpha_{f}=\frac{P_{A}}{P_{B}} \\
& \alpha_{H}=Q_{A} / Q_{B}=(P / l)_{A} /(P / l)_{B}
\end{aligned}
$$

where $A$ and $B$ are the gas species.

A typical hollow fiber includes two parts: a very thin dense film (skin) and a thick porous tubular support (core). The thick support provides mechanical strength and allows the gas to pass freely, while the dense layer performs the separation function. This implies that only a very thin layer controls the separation performance. Pesek and Koros [35] proposed that if the selectivity of a hollow fiber is higher than $80 \%$ of the intrinsic selectivity of the dense film (flat membrane), the gas transport is mostly controlled by the solution/diffusion mechanism. The hollow fiber skin layer thickness $(I)$ can then be estimated from the ratio of gas permeability (as measured from the flat membrane) and permeance under the same testing conditions (Eq.5) using the same material. In this case, the flat membrane permeability $\left(P_{f}\right)$ is assumed to be nominally equal to the hollow fiber thin dense skin permeability $\left(P_{h}\right)$. In other words, the structure of the polymer in the thin skin is the same as that found inside a dense flat membrane. Actually, the majority of the skin layer thickness evaluations were made from oxygen permeation measurements to get [35]:

$$
\begin{aligned}
& l=\frac{\text { Permeability }}{\text { Permeance }}=\frac{P}{Q} \\
& l_{A}=\frac{P_{A}}{Q_{A}}=\frac{P_{B} * \alpha_{f}}{Q_{B} * \alpha_{H}}=l_{B} * \frac{\alpha_{f}}{\alpha_{H}}
\end{aligned}
$$

\section{EXPERIMENTAL}

\subsection{Materials}

Ultem $^{\circledR} 1000$ pellets and Matrimid ${ }^{\circledR} 5218$ powders were purchased from GE Plastics and Huntsman Advanced Materials Americas Inc., respectively. Polyethersulfone (Ultrason E6020P) was graciously provided by BASF. All the polymers were dried overnight at $120^{\circ} \mathrm{C}$ before use. Their glass transition temperature and chemical structure are listed in Table 1. $\mathrm{N}$-methyl-2-pyrrolidone (NMP, bp $=204^{\circ} \mathrm{C}$, purity $>99.0 \%$ ), ethanol, methanol and hexanes were purchased from Caledon Laboratories Ltd. Tetrahydrofuran (THF, bp $=66^{\circ} \mathrm{C}$ ) was purchased from Fisher Chemicals. Lithium nitrate $\left(\mathrm{LiNO}_{3}\right)$ was purchased from Sigma-Aldrich. Polydimethylsiloxane (PDMS, Sylgard 184) was supplied by Dow Chemicals.

\subsection{Preparation of Flat Membrane}

Flat dense membranes were made by $10-12 \%$ wt. solution casting with NMP as the solvent [36-37]. The nascent films were heated in a vacuum oven at $200^{\circ} \mathrm{C}$ to evaporate the residual solvent for $24 \mathrm{~h}$.

\subsection{Preparation of Hollow Fiber Membranes}

\subsubsection{Dope Preparation}

The three polymer powders were dried in a vacuum oven at $120^{\circ} \mathrm{C}$ for $3 \mathrm{~h}$ to remove any moisture. The 
Table 1: Glass Transition Temperature and Chemical Structure of the Polymers Used

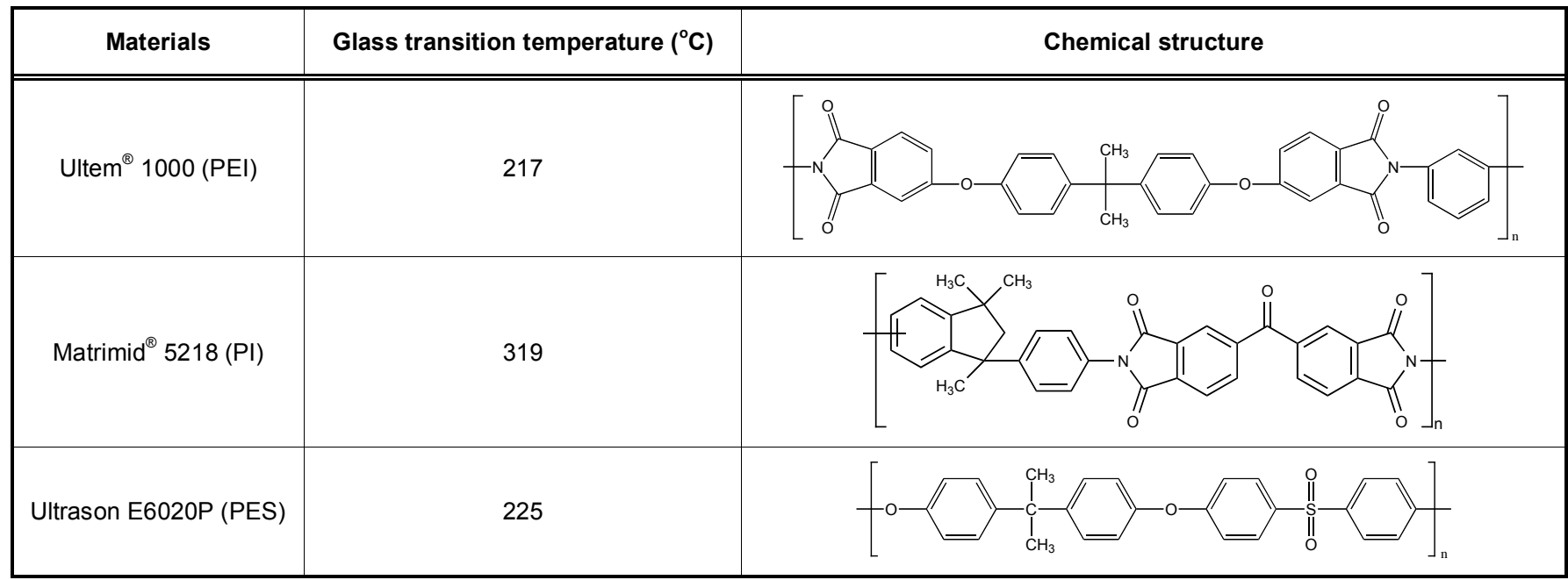

composition of the three polymer dopes is shown in Table 2. For the Ultem dope solution, $\mathrm{LiNO}_{3}$ was dissolved first in NMP using a sonication bath for $1 \mathrm{~h}$. The salt is used as a pore-forming agent to control the phase separation kinetics and final morphology of the porous support layer [20]. After the salt was dissolved, THF and the dried polymer powder were added in a vertical three-neck round-bottom flask using a mechanical stirrer for $24 \mathrm{~h}$.THF, due to its low boiling point, was vaporized in the air-gap distance to help form the skin layer outside the fibers.

For the Matrimid dope solution, ethanol as a nonsolvent was added to push the dope closer to the phase separation limit and improve the formation of the skin layer. The PES dope solution was simple using only NMP as the solvent.

Once fully dissolved, the transparent mixture was put on a metal filter unit with $15 \mu \mathrm{m}$ openings and filtered at 80 psi. The solution was finally put in the spinning reservoir for degassing (1 day).

\subsubsection{Fiber Spinning}

The asymmetric structure of the hollow fiber membranes was produced by a dry-wet spinning system (phase inversion) using a complete set-up from EMI (European Membrane Institute). This system includes two gear pumps, a spinning nozzle, a working tank, a control box, a coagulation bath, a steel rinsing bath (stainless isolated), a heating system, a rolling device and a filtration unit. Two metering pumps transfer precise amounts of the polymer dope solution (2-6 $\mathrm{ml} / \mathrm{min}$ ) and the bore fluid $(2-6 \mathrm{ml} / \mathrm{min})$ to the spinneret. Then, the polymer solution and non-solvent fluid go from the spinneret $\left(20-50^{\circ} \mathrm{C}\right)$ and the solvent evaporates in the air-gap $(0-15 \mathrm{~cm})$ region. Finally, the take-up $(10-30 \mathrm{~m} / \mathrm{min})$ unit collects the fibers from the coagulation bath. The spinning conditions for the three polymers are shown in Table 3, while Figure 1 presents the complete production line.

\subsubsection{Post-Treatment Procedure}

The collected fibers were then soaked in fresh tap water for $72 \mathrm{~h}$ (water changed every day) to remove the residual solvent. The wet fibers were then immersed in three methanol baths for $20 \mathrm{~min}$ each, followed by immersion in three hexane baths for $20 \mathrm{~min}$ each before drying in air at room temperature for two days. Then, the fibers were immersed in a $3 \%$ wt. silicone rubber solution (PDMS) for $5 \mathrm{~min}$ to seal the defects on the outer surface and dried at $60^{\circ} \mathrm{C}$ for $4 \mathrm{~h}$ under vacuum.

From the fibers produced, modules were also prepared by assembling 1-20 fibers of $40 \mathrm{~cm}$ long for a

Table 2: Compositions of the Dope Solutions for each Polymer Used (\% wt.)

\begin{tabular}{|c|c|c|c|c|}
\hline Materials & Polymer & NMP solvent & Volatile solvent (THF) & Non-solvent \\
\hline \hline Ultem $^{\circledR} 1000(\mathrm{PEI})$ & 30.0 & 35.0 & 34 & $1(\mathrm{LiNO})_{3}$ \\
\hline Matrimid $^{\circledR} 5218(\mathrm{PI})$ & 26.2 & 58.8 & - & $15(\mathrm{ethanol})$ \\
\hline Ultrason E6020P (PES) & 28.0 & 72.0 & - & - \\
\hline
\end{tabular}


Table 3: The Spinning Parameters for Ultem ${ }^{\circledR} 1000$, Matrimid ${ }^{\circledR} 5218$ and PES (E6020P)

\begin{tabular}{|c|c|c|c|c|c|c|c|}
\hline Spinning conditions & U301 & U302 & U303 & U304 & U305 & M264 & PES28 \\
\hline Dope composition & \multicolumn{5}{|c|}{$30 \%$ Ultem $+35 \% \mathrm{NMP}+34 \% \mathrm{THF}+1 \% \mathrm{LiNO}_{3}$} & $\begin{array}{c}26.2 \% \text { Matrimid }+58.8 \% \\
\text { NMP }+15 \% \text { ethanol }\end{array}$ & $\begin{array}{l}28 \% \text { PES + } \\
72 \% \text { NMP }\end{array}$ \\
\hline Bore liquid composition & \multicolumn{7}{|c|}{ 80/20 NMP/water } \\
\hline Dope flow rate $(\mathrm{ml} / \mathrm{min})$ & 4.5 & 3 & 3 & 3 & 3 & 3 & 3.75 \\
\hline Bore flow rate $(\mathrm{ml} / \mathrm{min})$ & 5 & 3 & 3 & 3 & 3 & 3 & 3.75 \\
\hline Air gap $(\mathrm{cm})$ & 4 & 4 & 7 & 10 & 10 & 4.5 & 3 \\
\hline Spinning temperature $\left({ }^{\circ} \mathrm{C}\right)$ & \multicolumn{5}{|c|}{23} & 45 & 23 \\
\hline Take-up speed (m/min) & 16.4 & 16.4 & 16.4 & 16.4 & 20.3 & 10.4 & 10.4 \\
\hline
\end{tabular}

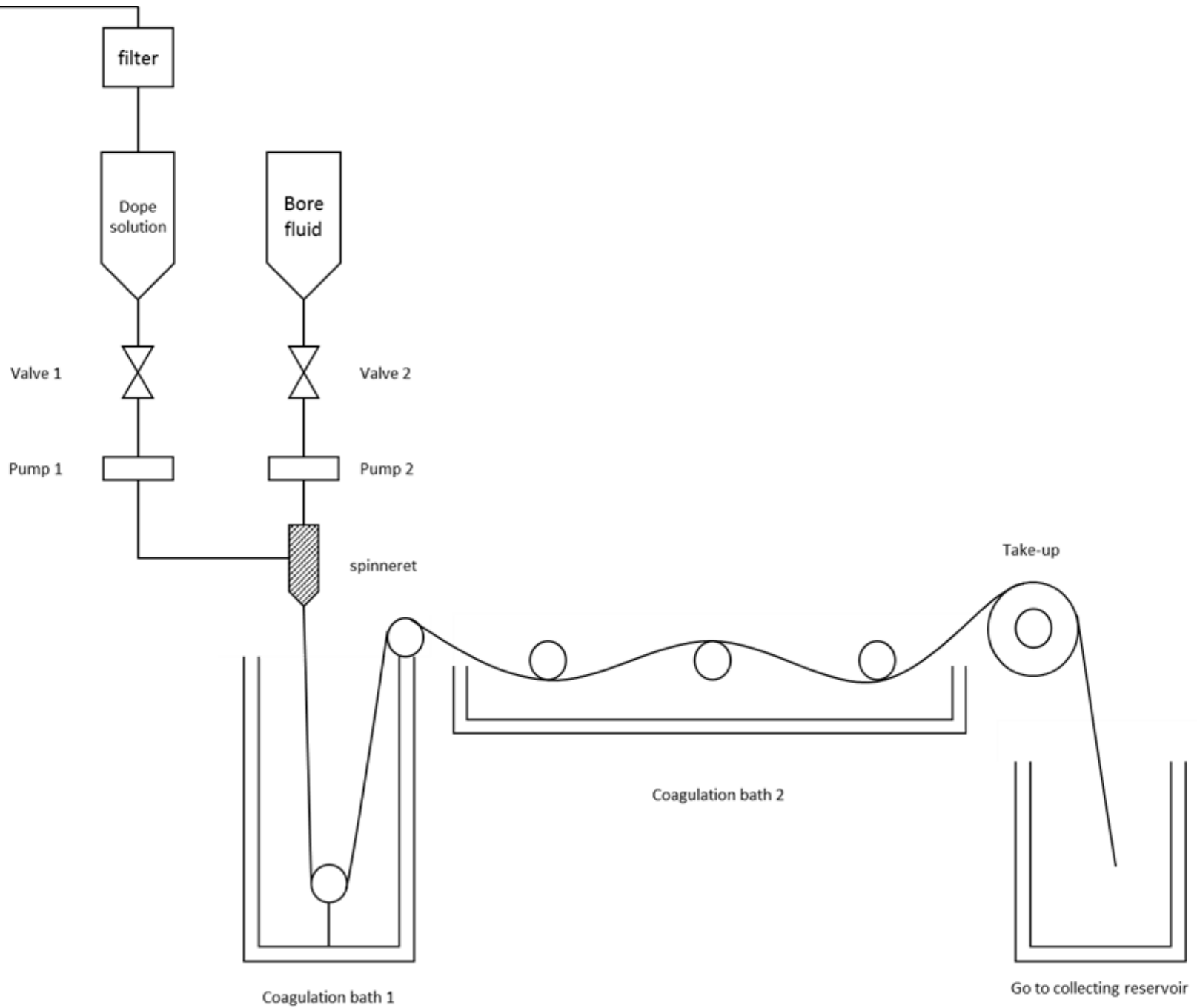

Figure 1: Schematic diagram of the spinning setup to produce the hollow fibers.

total membrane area of $5-50 \mathrm{~cm}^{2}$ calculated from the shell-side of the fiber diameter. The modules were sealed at both ends with epoxy (Elmer products, Inc. Fast Epoxy Cement). They were then left under ambient conditions for $24 \mathrm{~h}$ to assure complete epoxy curing.

\subsection{Characterization}

Thermogravimetric analysis (TGA) The weight curves (TGA) and their derivatives (DTG) were recorded using a TA Instruments model Q5000IR from 100 to $850^{\circ} \mathrm{C}$ at a heating rate of $10^{\circ} \mathrm{C} / \mathrm{min}$ under air. 


\section{Membrane Porosity and Density}

As the gases, should diffuse through the membrane pores, higher membrane porosity increases the membrane mass transfer coefficient. The membrane porosity $(\varepsilon)$ was calculated as [38]:

$\varepsilon=\frac{\frac{1}{\rho_{m}}-\frac{1}{\rho_{p}}}{\frac{1}{\rho_{m}}}$

where $\rho_{p}$ is the polymer density (see Table 1), while $\rho_{m}$ is the membrane density determined by the ratio of weight $\left(W_{m}\right)$ over volume $\left(V_{m}\right)$ as:

$\rho_{m}=\frac{W_{m}}{V_{m}}$

where

$V_{m}=\pi\left(D^{2}-d^{2}\right) L / 4$

with $D$ and $d$ being the average external and internal diameters, and $L$ the fiber's length.

\section{Mechanical Properties}

Tensile properties were measured on an Instron model 5565. From the stress-strain curves obtained, Young's modulus, tensile strength and elongation at break of the hollow fiber membranes were determined using ASTM D882. The initial grip separation was 100 $\mathrm{mm}$ and a deformation rate of $50 \mathrm{~mm} / \mathrm{min}$ was applied.

\section{Scanning Electron Microscopy (SEM)}

Scanning electron microscopy was performed to determine the dimensions of the hollow fibers in terms of skin layer thickness and diameters using a JEOL JSM-840A operated at $15-20 \mathrm{kV}$. The cross-sections were exposed by cryogenic fracture after immersion in liquid nitrogen.

\section{Dimensions}

Flat membranes thickness was measured using a micrometer (Starrett No. 732) with a deviation of $\pm 10 \%$. All the membranes had thickness between 35 and 50 $\mu \mathrm{m}$.

\section{Gas Permeation}

The gas transport properties were obtained using a variable pressure (constant volume) method. Figure 2 presents a scheme of the experimental set-up which is modified from our previous work [39], by the addition of a module for hollow fiber membranes (\#10). The gas to be tested was introduced from a cylinder (\#2) on the upstream side of flat membranes or the shell-side feed of hollow fibers, while the permeant pressure (down side of flat membranes or bore-side of hollow fibers) was recorded using a pressure transducer. The permeance $\left(10^{-6} \mathrm{~cm}^{3}(\mathrm{STP}) \mathrm{cm}^{-2} \mathrm{~s}^{-1} \mathrm{~cm} \mathrm{Hg}\right)$ was determined as:

$$
Q=22412 \times \frac{V}{A R T} \times \frac{1}{\Delta p} \times \frac{d p}{d t}
$$

where $A$ is the membrane area $\left(\mathrm{cm}^{2}\right) ; p$ is the pressure (psi); $V$ is the downstream volume $\left(\mathrm{cm}^{3}\right) ; R$ is the universal gas constant $\left(6236.56 \mathrm{~cm}^{3} \mathrm{cmHg} / \mathrm{mol} \mathrm{K}\right) ; T$ is the absolute temperature $(\mathrm{K})$; and $d p / d t$ is the permeation rate (psi/s).The values are commonly reported in units of GPU (gas permeation units) defined as: $1 \mathrm{GPU}=1$ Barrer $/ 1 \mathrm{micron}\left(1\right.$ Barrer $=10^{-10}$ $\mathrm{cm}^{3}(\mathrm{STP}) \mathrm{cm}^{-2} \mathrm{~s}^{-1} \mathrm{cmHg}$ ).

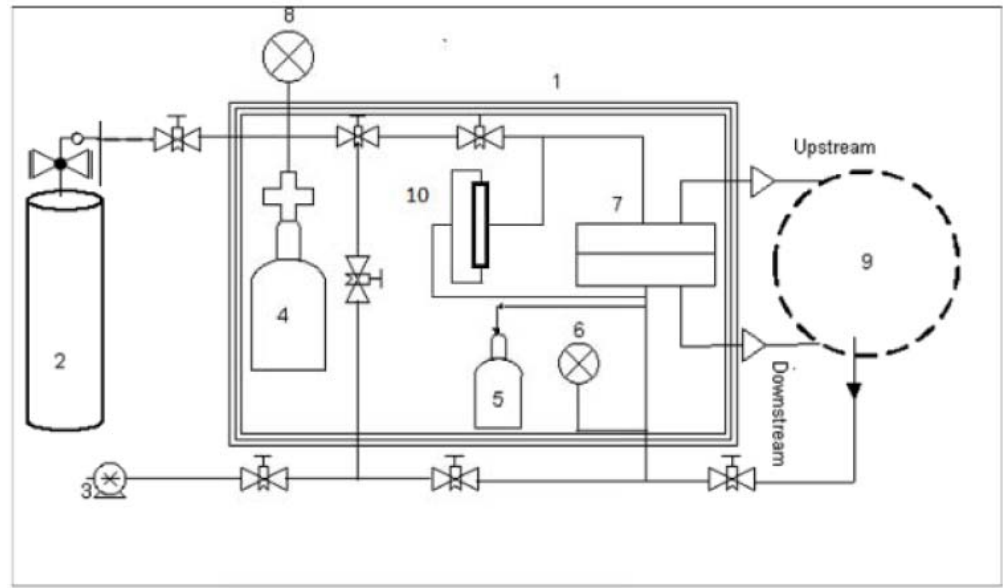

Figure 2: Permeability and selectivity measurement set up. 1: Heated chamber; 2: supply gas cylinder; 3 : vacuum pump; 4: feed reservoir; 5: permeate reservoir; 6: downstream pressure transducer (-15 to 15 psi); 7: cell for flat membranes; 8: upstream pressure transducer (0-1000 psi); 9: 2-position and 10 ports valve and gas chromatograph; 10: cell for hollow fibers. 


\section{RESULTS AND DISCUSSION}

\subsection{Morphology of the Hollow Fibers}

The fiber morphology was examined by SEM and the image of the three hollow fibers are presented in Figures 3-5. It can be seen that a concentric cylinder morphology was obtained for all the hollow fibers. The good concentricity indicates a relatively uniform morphology, which potentially allows using a high feed pressure across the hollow fiber membrane [40]. The dense skin layer, transition layer and open porous substructure of the hollow fibers are obviously observed in the images. As seen in Figure 5, two long and wide finger-like structure close to the inner and outer side of the membrane are observed in PES, while only one finger-like structure is formed in Ultem (Figure 3). The morphology of Matrimid is different without finger-like, but mainly a sponge-like structure. Additionally, a nodular structure can be seen in Figure 4. As reported by Kesting [41], large finger-like macrovoids is generally formed when the coagulation process is fast, while a slow coagulation rate results in a porous sponge-like structure. In PES and Ultem, no non-solvent was used while in the case of Matrimid, $15 \%$ ethanol as non-solvent was added in the polymer solution. Therefore, the addition of a non-solvent in the polymer solution played an important role in controlling the morphology.

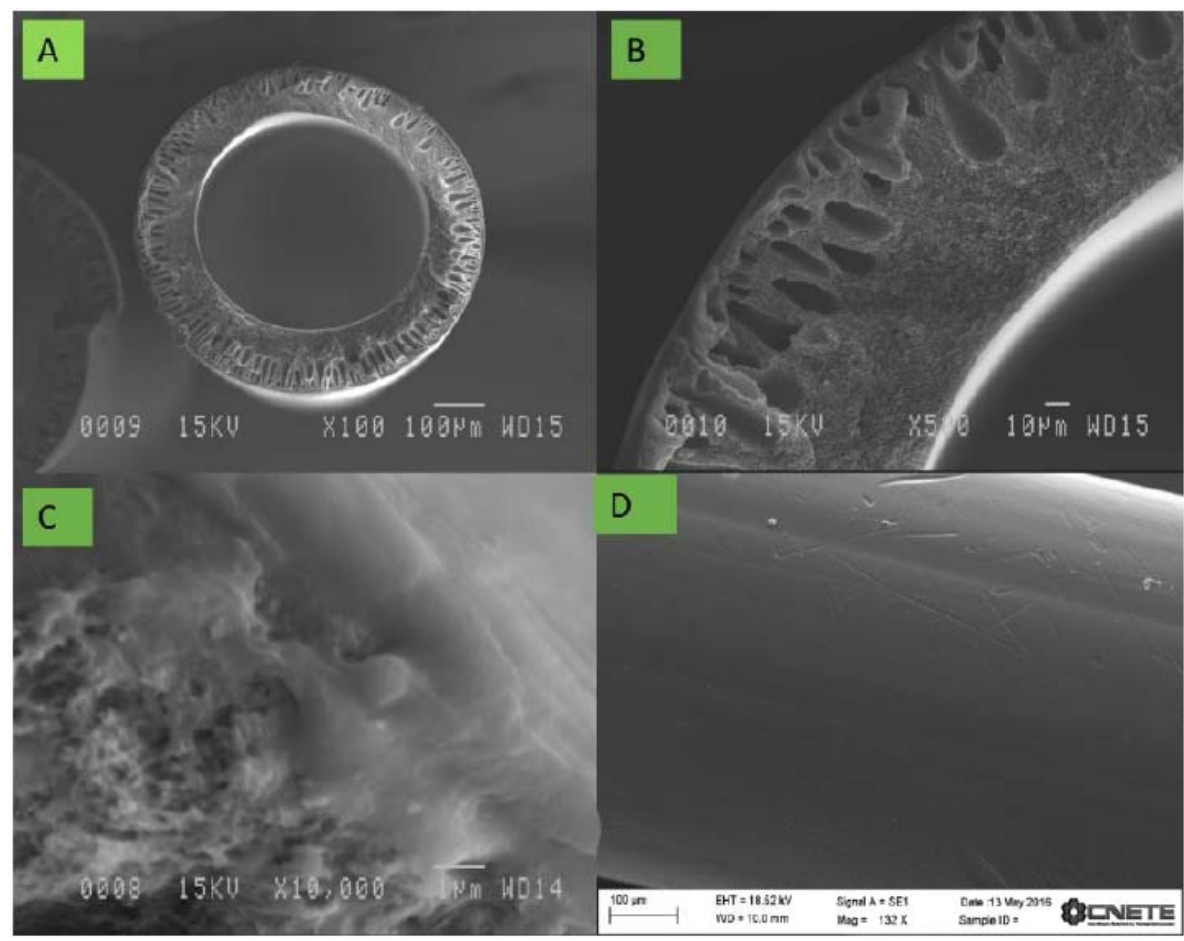

Figure 3: SEM images of U305 hollow fiber asymmetric structure. (A) Overall cross-section of a fiber (100X); (B) cross-section (500X); (C) cross-section (10000X); (D) outer side of the dense skin surface.
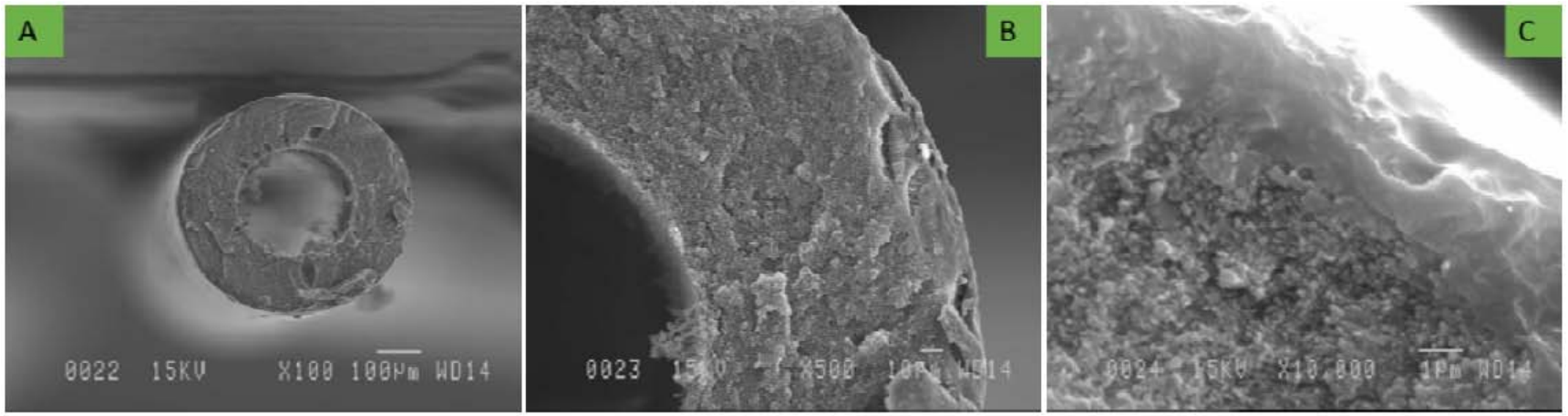

Figure 4: SEM images of M264 hollow fiber asymmetric structure. (A) Overall cross-section of a fiber (100X); (B) cross-section (500X); (C) cross-section (10000X). 


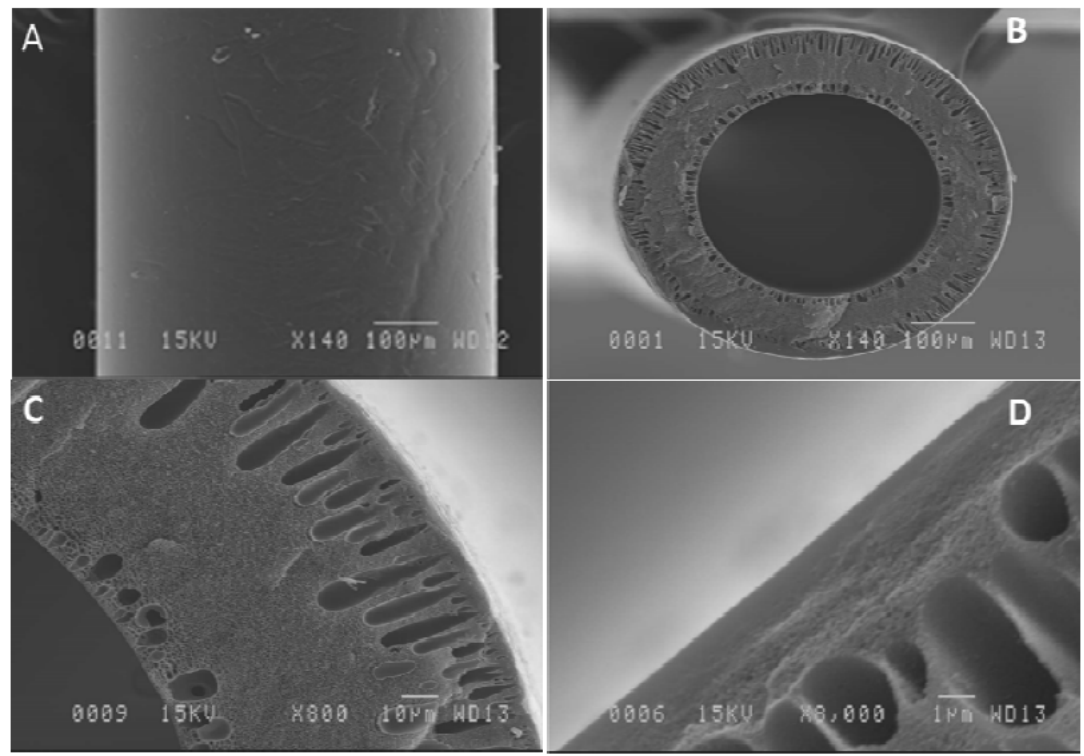

Figure 5: SEM images of PES28 hollow fibers asymmetric structure. (A) Outer surface of the dense skin; (B) overall crosssection of a fiber; (C) membrane thickness; (D) skin layer thickness.

\subsection{Polymer Membrane Characteristics}

\subsubsection{Density and Porosity}

Porosity is representative of the morphology of the hollow fibers as higher porosity (lower density) indicates a higher amount of free volume in the membrane. Here, Matrimid has higher porosity, followed by Ultem and PES (Table 4). However, the porosities reported in Table $\mathbf{4}$ are lower than the values for Ultem and PES reported in ref. [42]. In the latter, asymmetric membranes made from $15 \%$ Ultem or $15 \%$ PES in $85 \%$ NMP with $0.05 \%$ water were produced leading to $79.8 \%$ and $83.4 \%$ of porosity, respectively.

\subsubsection{Mechanical Properties}

In Table 5, the Young's modulus reported for the hollow fibers was obtained using dynamic mechanical analysis from the slope of the stress-strain curves at low deformation (linear elasticity), while the values for the neat polymer were obtained from the supplier (GE Plastics, Huntsman Advanced Materials Americas Inc. and BASF).

Table 5 also reports the elongation at break and tensile strength of the three polymers and their respective hollow fibers. As expected, the porous structure and thin dense skin layer led to lower Young's modulus compared to the neat polymer. The elongation at break and tensile strength also decreased, especially for PES which has a very thin skin layer (53 nm) and a wide finger-like structure in the membrane.

\subsubsection{Thermal Analysis}

Thermogravimetric analysis (TGA) is providing information about the thermal stability of the hollow fibers compared to their neat state (Figure 6). The characteristic temperatures from TGA curves $(5 \%$ and $10 \%$ weight loss) and the peak temperature in the derivative plots (DTG) are listed in Table 6 . The TGA results indicate that the weight is almost constant (plateau) up to $440^{\circ} \mathrm{C}$ which reflects the high thermal stability of these membranes. They also show the absence of remnant NMP (solvent with a boiling point of $204.5^{\circ} \mathrm{C}$ ). But in all cases, the $\mathrm{T}_{\mathrm{d} 5 \%}$ of the hollow fibers are lower than the neat polymers (before processing). This is likely associated to the cross-linked silicone rubber (PDMS) coating on the membranes as PDMS thermally decomposes around $360^{\circ} \mathrm{C}$ [43].

Table 4: Density and Porosity of the three Hollow Fiber Membranes

\begin{tabular}{|c|c|c|c|}
\hline Materials & Membrane density $\left(\mathbf{g} / \mathbf{c m}^{3}\right)$ & Polymer density $\mathbf{( g / \mathbf { c m } ^ { 3 } )}$ & Membranes porosity $(\%)$ \\
\hline \hline Ultem $® 1000(\mathrm{PEI})$ & 0.528 & 1.27 & 55.9 \\
\hline Matrimid® 5218 (PI) & 0.528 & 1.20 & 58.4 \\
\hline Ultrason E6020P (PES) & 0.744 & 1.38 & 46.1 \\
\hline
\end{tabular}


Table 5: Young's Modulus, Tensile Strength and Elongation at Break of the Neat Polymers and the Hollow Fiber Produced

\begin{tabular}{|c|c|c|c|c|c|c|}
\hline Materials & $\begin{array}{l}\text { Young's modulus } \\
\text { (MPa) }\end{array}$ & $\begin{array}{l}\text { S.D. } \\
(\%)\end{array}$ & $\begin{array}{c}\text { Elongation at break } \\
(\%)\end{array}$ & $\begin{array}{l}\text { S.D. } \\
(\%)\end{array}$ & $\begin{array}{c}\text { Tensile } \\
\text { strength (MPa) }\end{array}$ & S.D. (\%) \\
\hline U305 & 132 & 5 & 44 & 4 & 58.5 & 7.5 \\
\hline Ultem $^{\circledR} 1000$ (PEI) & 3585 & - & 60 & - & 105 & - \\
\hline M264 & 121 & 4 & 29 & 6 & 54.8 & 1.2 \\
\hline Matrimid $^{\circledR} 5218(\mathrm{Pl})$ & 2896 & - & 49 & - & 86.9 & - \\
\hline PES28 & 72 & 10 & 85 & 14 & 5.2 & 0.6 \\
\hline Ultrason E6020P (PES) & 2650 & - & $50-100$ & - & 85 & - \\
\hline
\end{tabular}

S.D. = standard deviation which are not reported by the supplier.

Table 6: Results of TGA and DTG for the three Polymer Hollow Fiber Membranes

\begin{tabular}{|c|c|c|c|}
\hline Polymer & $\mathbf{T}_{\mathrm{d} 5 \%}\left({ }^{\circ} \mathrm{C}\right)$ & $\mathbf{T}_{\mathrm{d} 10 \%}\left({ }^{\circ} \mathrm{C}\right)$ & DTG peak $\left({ }^{\circ} \mathrm{C}\right)$ \\
\hline \hline Ultem ${ }^{\circ}$ & 502 & 510 & 520 \\
\hline U305 & 437 & 465 & 487 \\
\hline Matrimid® & 480 & 491 & 499 \\
\hline M264 & 474 & 487 & 489 \\
\hline PES & 501 & 524 & 561 \\
\hline PES28 & 485 & 515 & 555 \\
\hline
\end{tabular}

TheTGA traces reported in Figure 3 show that the PES membrane has the same thermal behavior as the neat PES. However, the TGA curves of Matrimid and Ultem membrane display slightly lower stability than their corresponding neat polymer. But overall, the systems are different and this may be associated to the different porosity and the absence of additive in the PES membrane preparation (section 3.2). Matrimid and Ultem membranes have higher porosity than the PES membrane (see Table 4). Also, $\mathrm{LiNO}_{3}$ as a poreforming agent in the Ultem dope composition contributes to the enhanced porosity of Ultem membranes. As expected, materials with higher porosity have a larger available surface area leading to better contact with air. So better diffusion of the gas molecules leads to lower thermal stability via faster reaction kinetics and less mass transfer resistance. Nevertheless, the results indicate that these three materials could be used in high temperature separation processes.

\subsection{Gas Transport Properties}

Table 7 presents the gas separation performance of the flat membranes at $35^{\circ} \mathrm{C}$ and $10 \mathrm{~atm}$. The $\mathrm{O}_{2}$ permeability of Ultem, Matrimid and PES are 0.4, 1.32 and 0.44 Barrer respectively, leading to $\mathrm{O}_{2} / \mathrm{N}_{2}$ selectivity of 7.6. 7.2 and 6.3, respectively.

For the hollow fibers produced, Table 8 presents the gas transport properties measured at $30^{\circ} \mathrm{C}$ and $2 \mathrm{~atm}$. Each measurement was made in triplicate with three different membranes of the same material. Comparison of the gas transport results shows that the highest permeance for all the gases was obtained for PES. However, all the selectivities for $\mathrm{H}_{2} / \mathrm{N}_{2}, \mathrm{H}_{2} / \mathrm{CH}_{4}$, $\mathrm{CO}_{2} / \mathrm{CH}_{4}, \mathrm{CO}_{2} / \mathrm{N}_{2}$ and $\mathrm{O}_{2} / \mathrm{N}_{2}$ are lower than for the other two polymers. Matrimid was the best material for gas separation, especially for $\mathrm{CO}_{2} / \mathrm{CH}_{4}$ and $\mathrm{CO}_{2} / \mathrm{N}_{2}$. Ultem is a lower cost material compared to Matrimid, and other commercial polyimides. Ultem also has higher mechanical properties and performs in continuous use up to $170^{\circ} \mathrm{C}$ and even up to its glass transition temperature $\left(217^{\circ} \mathrm{C}\right)$. The selectivity of $\mathrm{H}_{2} / \mathrm{N}_{2}$ and $\mathrm{H}_{2} / \mathrm{CH}_{4}$ can reach up to 117 and 91.7 which are quite high. So, the final material selection must be made depending on the industrial application and which gas separation must be performed.

The $\mathrm{O}_{2} / \mathrm{N}_{2}$ selectivities of the hollow fiber membranes of Matrimid and Ultem are higher than the dense films of known thickness (the intrinsic $\mathrm{O}_{2} / \mathrm{N}_{2}$ 

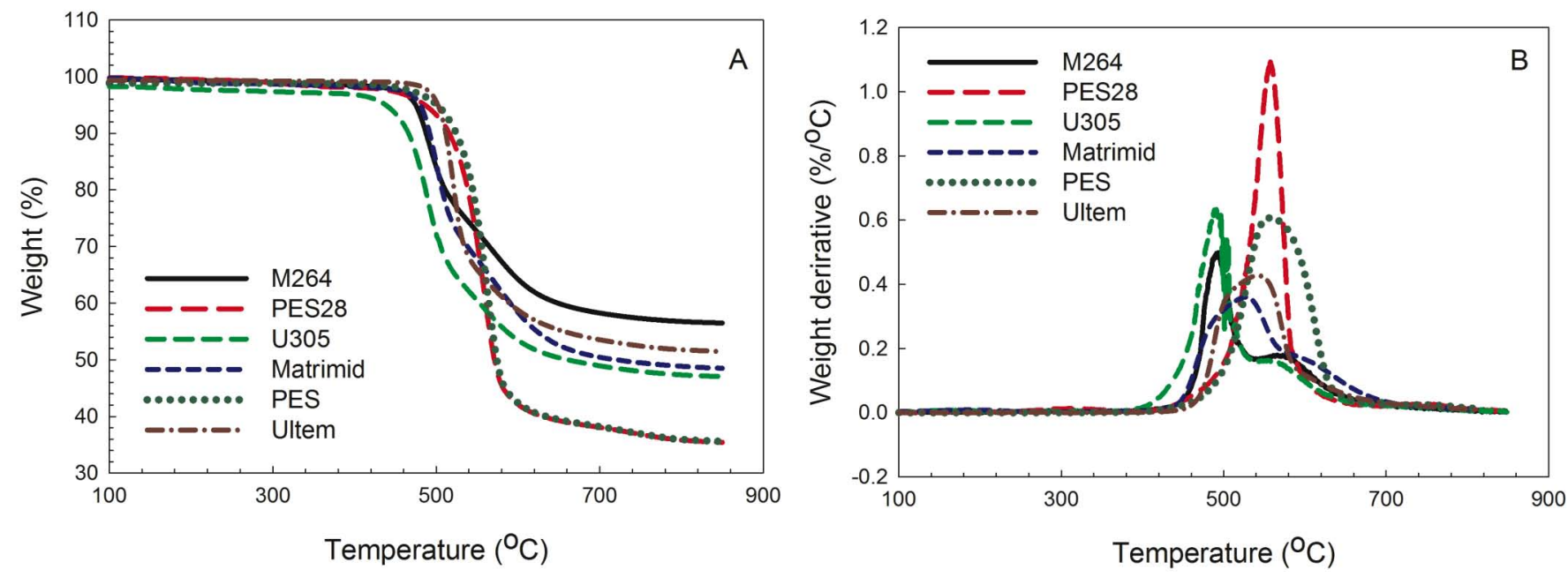

Figure 6: Three commercial materials and hollow fiber membranes thermal stability: (A) TGA and (B) DTG.

Table 7: Gas Separation Performance of the Flat Membranes for the Three Polymers $\left(35^{\circ} \mathrm{C}\right.$ and $\left.10 \mathrm{~atm}\right)$

\begin{tabular}{|c|c|c|c|c|c|}
\hline Membranes & Unit & Gases & Ultem & Matrimid & PES \\
\hline \multirow{3}{*}{ Permeability } & \multirow{3}{*}{ Barrer } & $\mathrm{H}_{2}$ & 6.53 & 18.0 & 6.80 \\
\hline & & $\mathrm{O}_{2}$ & 0.40 & 1.32 & 0.44 \\
\hline & & $\mathrm{CH}_{4}$ & 0.04 & 0.19 & 0.10 \\
\hline \multirow{4}{*}{ Selectivity } & \multirow{4}{*}{-} & $\mathrm{H}_{2} / \mathrm{N}_{2}$ & 130 & 94.2 & 67.6 \\
\hline & & $\mathrm{H}_{2} / \mathrm{CH}_{4}$ & 163 & 98.2 & 97.4 \\
\hline & & $\mathrm{CO}_{2} / \mathrm{N}_{2}$ & 29.2 & 35.0 & 46.1 \\
\hline & & $\mathrm{CO}_{2} / \mathrm{CH}_{4}$ & 36.5 & 34.0 & 32.0 \\
\hline
\end{tabular}

Table 8: Gas Separation Performance of the Hollow Fiber Membranes for the Three Polymers $\left(30^{\circ} \mathrm{C}\right.$ and 2 atm)

\begin{tabular}{|c|c|c|c|c|c|}
\hline Membranes & Unit & Gases & U305 & M264 & PES28 \\
\hline \multirow{3}{*}{ Permeance } & \multirow{3}{*}{ GPU } & $\mathrm{H}_{2}$ & 38.5 & 56.4 & 58.7 \\
\hline & & $\mathrm{O}_{2}$ & 2.89 & 3.88 & 8.38 \\
\hline & & $\mathrm{CH}_{4}$ & 0.42 & 0.73 & 2.66 \\
\hline \multirow{4}{*}{ Selectivity } & \multirow{4}{*}{-} & $\mathrm{H}_{2} / \mathrm{N}_{2}$ & 117 & 109 & 37.1 \\
\hline & & $\mathrm{H}_{2} / \mathrm{CH}_{4}$ & 91.7 & 77.3 & 22.1 \\
\hline & & $\mathrm{CO}_{2} / \mathrm{N}_{2}$ & 22.8 & 34.0 & 18.6 \\
\hline & & $\mathrm{CO}_{2} / \mathrm{CH}_{4}$ & 17.9 & 24.3 & 11.1 \\
\hline
\end{tabular}


Table 9: Skin Layer Thickness Evaluated by from $\mathrm{O}_{2}$ Permeability and Permeance

\begin{tabular}{|c|c|c|c|}
\hline Polymer & U305 & M264 & P28 \\
\hline \hline Skin layer thickness $(\mathrm{nm})$ & 138 & 340 & 52.5 \\
\hline
\end{tabular}

selectivities). This is due to a high shear and high chain orientation in the thin layer induced by the spinning process in the polymer matrix. This may have changed the packing density of polymer chains and free volume resulting in a reduction of gas mobility in the denseselective layer and a change in selectivity compared to the flat membrane. In our case, the take-up speed for Ultem and Matrimid hollow fiber membranes are 20 and $10 \mathrm{~m} / \mathrm{min}$ (see Table 3). The high shear allows improving the $\mathrm{O}_{2} / \mathrm{N}_{2}$ selectivities. The average selectivities of PES asymmetric membrane samples were within $84 \%$ of the intrinsic $\mathrm{O}_{2} / \mathrm{N}_{2}$ selectivities of PES. The skin layer thickness was calculated by Eq. (5) and the values are listed in Table 9. Matrimid hollow fiber has the thickest skin layer, and PES has a very thin one. Because for each polymer different spinning conditions were used, it is difficult to fully compare the results. In general, longer air gap leads to thicker skin layer, while higher take-up speed produces thinner skin layer. U305 being prepared with an air gap of $10 \mathrm{~cm}$ with the presence of a volatile solvent in the dope has thicker dense skin layer. On the other hand, a higher take-up speed of $20 \mathrm{~cm} / \mathrm{min}$ was used in this case. Therefore, the final skin layer thickness obtained was only of $138 \mathrm{~nm}$. M264 fiber was made with an air gap of $4 \mathrm{~cm}$ and a lower take-up speed of $10 \mathrm{~cm} / \mathrm{min}$, so the skin thickness was thicker $(340 \mathrm{~nm})$. For the PES28 membrane prepared with an air gap of $4 \mathrm{~cm}$ and a take-up speed of $10 \mathrm{~cm} / \mathrm{min}$, and no evaporation of a volatile solvent from the dope, produced a skin layer of only $52.5 \mathrm{~nm}$.

Usually, hollow fibers have a thin skin layer on the order of $100 \mathrm{~nm}$ without defects or substructure resistance and these are considered as ideal membrane [44]. Comparing the skin layer thickness for the three hollow fiber membranes, U305 is very close to the ideal thickness $(138 \mathrm{~nm})$, while the M264 membrane is possibly above the optimum thickness which has a direct effect of the gas separation performance.

\subsection{Permeance and Ideal Selectivity of Single Fiber and Modules}

To get closer to real applications, the properties of a single fiber are now compared with modules based on 5,10 or 20 fibers assembled in a tube. Table 10 presents a comparison the results obtained for the different gases studied. With increasing fiber number, higher permeance and lower selectivity were obtained with the exception of $\mathrm{CH}_{4} / \mathrm{N}_{2}$. This result can be attributed to possible defects created during the epoxy

Table 10: Comparison of Single Fiber and Fiber Modules (10 and 20 Fibers) for PES Membrane

\begin{tabular}{|c|c|c|c|c|c|c|}
\hline Membranes & Gas & PES (1 fiber) & \multicolumn{2}{|c|}{ Module (10 fibers) } & \multicolumn{2}{|c|}{ Module (20 fibers) } \\
\hline Test condition $\left({ }^{\circ} \mathrm{C} / \mathrm{psi}\right)$ & - & $30 / 30$ & $30 / 30$ & $30 / 100$ & $30 / 30$ & $30 / 100$ \\
\hline \multirow{5}{*}{ Permeance (GPU) } & $\mathrm{H}_{2}$ & 58.7 & 63.9 & 64.2 & 98.9 & 71.4 \\
\hline & $\mathrm{CO}_{2}$ & 29.6 & 34.9 & 37.3 & 54.4 & 46.0 \\
\hline & $\mathrm{O}_{2}$ & 8.38 & 9.33 & 9.59 & 14.4 & 11.8 \\
\hline & $\mathrm{CH}_{4}$ & 2.66 & 3.20 & 3.34 & 8.23 & 6.32 \\
\hline & $\mathrm{N}_{2}$ & 1.59 & 1.97 & 2.13 & 3.41 & 3.77 \\
\hline \multirow{6}{*}{ Selectivity (-) } & $\mathrm{H}_{2} / \mathrm{CH}_{4}$ & 22.0 & 20.0 & 19.2 & 12.0 & 11.3 \\
\hline & $\mathrm{H}_{2} / \mathrm{N}_{2}$ & 37.0 & 32.4 & 30.1 & 29.0 & 18.9 \\
\hline & $\mathrm{CO}_{2} / \mathrm{CH}_{4}$ & 11.1 & 10.9 & 11.2 & 6.61 & 7.28 \\
\hline & $\mathrm{CO}_{2} / \mathrm{N}_{2}$ & 18.6 & 17.7 & 17.5 & 16.0 & 12.2 \\
\hline & $\mathrm{O}_{2} / \mathrm{N}_{2}$ & 5.29 & 4.74 & 4.50 & 4.22 & 3.13 \\
\hline & $\mathrm{CH}_{4} / \mathrm{N}_{2}$ & 1.68 & 1.62 & 1.57 & 2.41 & 1.68 \\
\hline
\end{tabular}


Table 11: Comparison of Single Fiber and Fiber Modules (5 Fibers) for Matrimid ${ }^{\circledR} 5218$ M264 Membranes

\begin{tabular}{|c|c|c|c|c|}
\hline Membranes & Unit & Gas & one fiber & 5 fibers \\
\hline \multirow{4}{*}{ Permeance } & \multirow{4}{*}{ GPU } & $\mathrm{H}_{2}$ & 58.2 & 57.2 \\
\hline & & $\mathrm{CO}_{2}$ & 14.4 & 17.8 \\
\hline & & $\mathrm{O}_{2}$ & 3.21 & 4.24 \\
\hline & & $\mathrm{N}_{2}$ & 0.64 & 0.66 \\
\hline \multirow{3}{*}{ Selectivity } & \multirow{3}{*}{-} & $\mathrm{H}_{2} / \mathrm{CH}_{4}$ & 77.6 & 76.3 \\
\hline & & $\mathrm{H}_{2} / \mathrm{N}_{2}$ & 90.9 & 86.7 \\
\hline & & $\mathrm{CO}_{2} / \mathrm{CH}_{4}$ & 19.2 & 23.7 \\
\hline
\end{tabular}

curing (drying too fast) which is acting as a seal between the fibers and/or the metal tube. This effect may be more important as feed pressure increases. This is why the epoxy used was changed to a longer drying time and modules with only 5 fibers were made to limit the area to be covered. These results (Matrimid) are also presented in Table 11. These results clearly indicate that the choice of the epoxy type is very important for module building.

\subsection{Optimization of the Spinning Parameters for Ultem $^{\circledR} 1000$}

The spinning parameters also influence the phase separation kinetics and thus strongly determine the final morphology and performance of the membranes. Table 3 listed the spinning parameters used in the

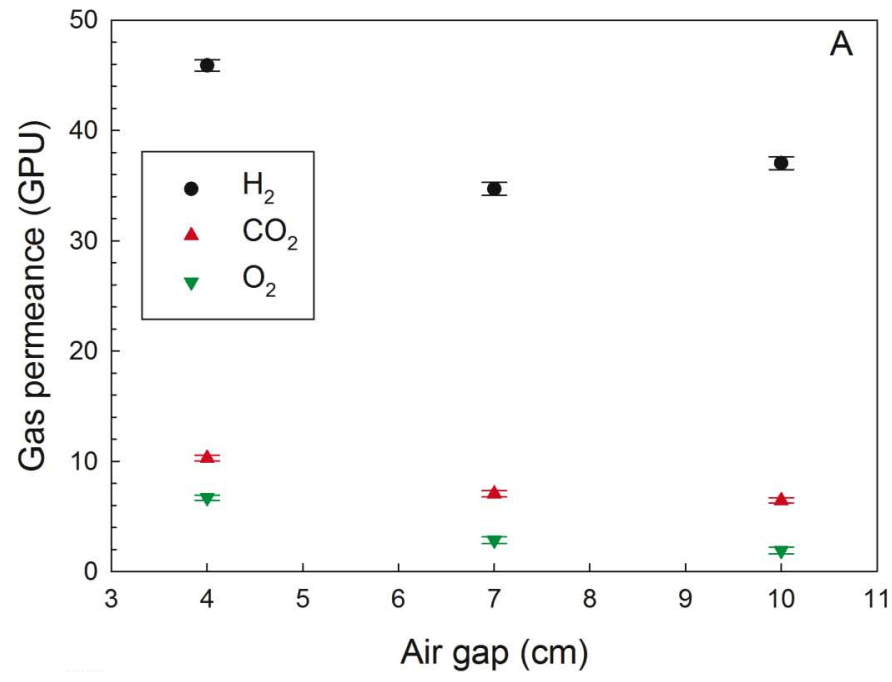

Figure 7: Gas permeation properties of U302, U303 and U304 membranes as a function of the air gap distance.

preparation of Ultem ${ }^{\circledR} 1000$ hollow fiber membranes. As expected, the bore fluid provides support to the nascent hollow fiber membrane. Since the results obtained for U301 membranes were shown to be nonselective because the bore fluid flow rate was too high, this membrane will not be discussed below.

The membranes U302, U303 and U304 have the same spinning conditions except for the air gap varying from 4 , to 7 and $10 \mathrm{~cm}$, respectively. $\mathrm{H}_{2}, \mathrm{CO}_{2}$ and $\mathrm{O}_{2}$ pure gas permeances and $\mathrm{H}_{2} / \mathrm{CH}_{4}, \mathrm{H}_{2} / \mathrm{N}_{2}, \mathrm{CO}_{2} / \mathrm{CH}_{4}$ and $\mathrm{O}_{2} / \mathrm{N}_{2}$ ideal selectivities as a function of the air gap distance at $30^{\circ} \mathrm{C}$ and 100 psi feed pressure are reported in Figure 7. It can be seen that the permeance slightly decreases and selectivity increases with the air gap distance because a longer air gap induces defects in the external surfaces. Also longer air gap produces

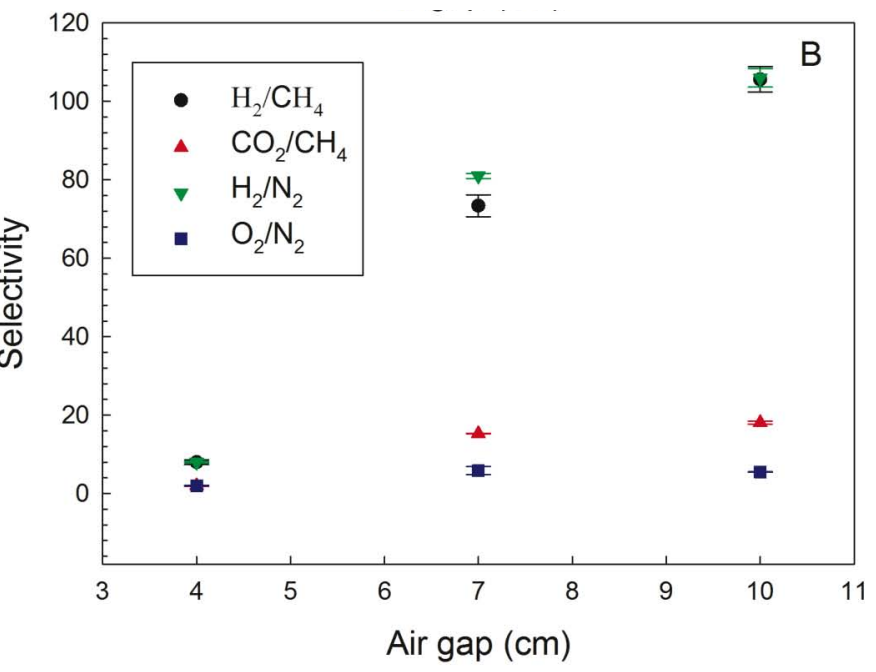


Table 12: The Effect of Take-Up Speed on Gas Separation Performance for Ultem Hollow Fiber Membranes

\begin{tabular}{|c|c|c|c|c|c|c|}
\hline \multicolumn{2}{|c|}{ Membrane } & \multirow[t]{2}{*}{ Gas } & \multicolumn{2}{|c|}{ U305 } & \multicolumn{2}{|c|}{ U304 } \\
\hline Test condition & ${ }^{\circ} \mathrm{C} / \mathrm{psi}$ & & $30 / 30$ & $30 / 100$ & $30 / 30$ & $30 / 100$ \\
\hline \multirow{5}{*}{ Permeance } & \multirow{5}{*}{ GPU } & $\mathrm{H}_{2}$ & 38.5 & 36.8 & 27.3 & 37.7 \\
\hline & & $\mathrm{CO}_{2}$ & 7.53 & 7.04 & 6.3 & 6.45 \\
\hline & & $\mathrm{O}_{2}$ & 2.89 & 2.55 & 1.95 & 1.92 \\
\hline & & $\mathrm{CH}_{4}$ & 0.42 & 0.41 & 0.39 & 0.35 \\
\hline & & $\mathrm{N}_{2}$ & 0.33 & 0.33 & 0.39 & 0.35 \\
\hline \multirow{6}{*}{ Selectivity } & \multirow{6}{*}{-} & $\mathrm{H}_{2} / \mathrm{CH}_{4}$ & 91.7 & 89.8 & 69.1 & 106 \\
\hline & & $\mathrm{H}_{2} / \mathrm{N}_{2}$ & 117 & 111 & 70 & 106 \\
\hline & & $\mathrm{CO}_{2} / \mathrm{CH}_{4}$ & 17.9 & 17.2 & 15.9 & 18.1 \\
\hline & & $\mathrm{CO}_{2} / \mathrm{N}_{2}$ & 22.8 & 21.3 & 16.2 & 18.1 \\
\hline & & $\mathrm{O}_{2} / \mathrm{N}_{2}$ & 8.8 & 7.7 & 5.0 & 5.39 \\
\hline & & $\mathrm{CH}_{4} / \mathrm{N}_{2}$ & 1.27 & 1.24 & 1.01 & 1.01 \\
\hline
\end{tabular}

more compact and thicker outer skin layers, leading to improved selectivity [44].

On the other hand, the membranes U304 and U305 were prepared at different take-up speeds. Higher speed produces a higher extrusion rate (shear rate). For U305, increased shear can create an oriented and highly ordered active layer which can produce selectivities significantly higher than the intrinsic value of the isotropic polymer $[40,46]$. The $\mathrm{O}_{2} / \mathrm{N}_{2}$ selectivity of U305 are 8.8 and 7.7, which are higher than the intrinsic value of their flat membrane of 7.6 (see Table 12).

\subsection{Effect of Operation Temperature and Feed Pressure on Ultem1000 Hollow Fiber Performance}

Additional measurements were made for U304 membranes at different temperature $\left(30,50\right.$, and $\left.70^{\circ} \mathrm{C}\right)$ to determine the effect of this parameter on the gas transport properties. The results of Figure 8A show that, as expected, $\mathrm{H}_{2}$ and $\mathrm{CH}_{4}$ permeances increase with increasing temperature, but the ideal permselectivity decreases. Interestingly, increasing the feed pressure had a beneficial effect on the $\mathrm{H}_{2} / \mathrm{CH}_{4}$ selectivity as shown in Figure 8B. Increasing pressure may affect both void size and thickness of the effective thin layer (elastic/deformable fibers) and, as shown in Figure 8B, these combined effects result in the $\mathrm{H}_{2}$ molecule with smaller kinetic diameter to diffuse faster than $\mathrm{CH}_{4}$ with increasing pressure leading to selectivity increases.

\section{CONCLUSION}

In this work, three different commercial polymers (Ultem, Matrimid and Ultrason) were used to prepare

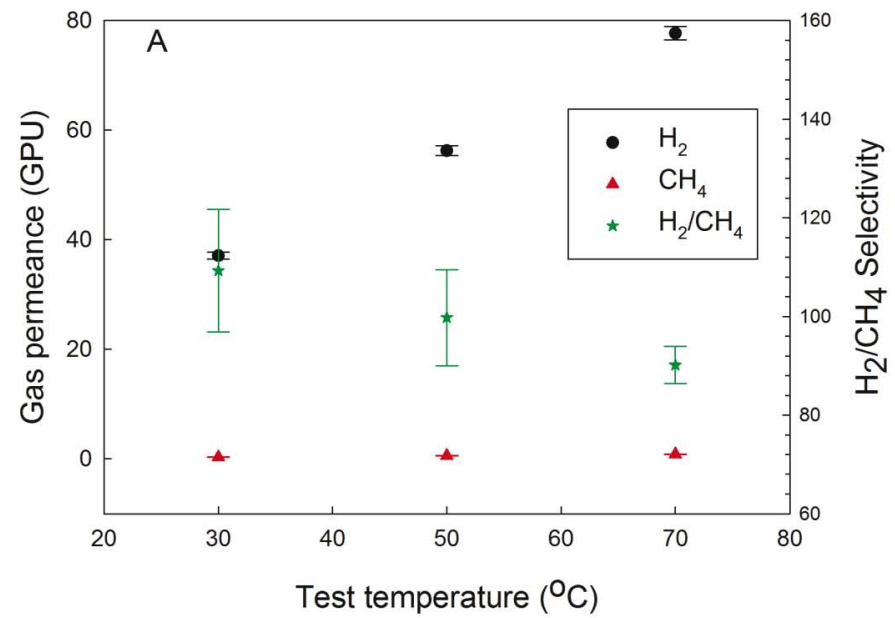

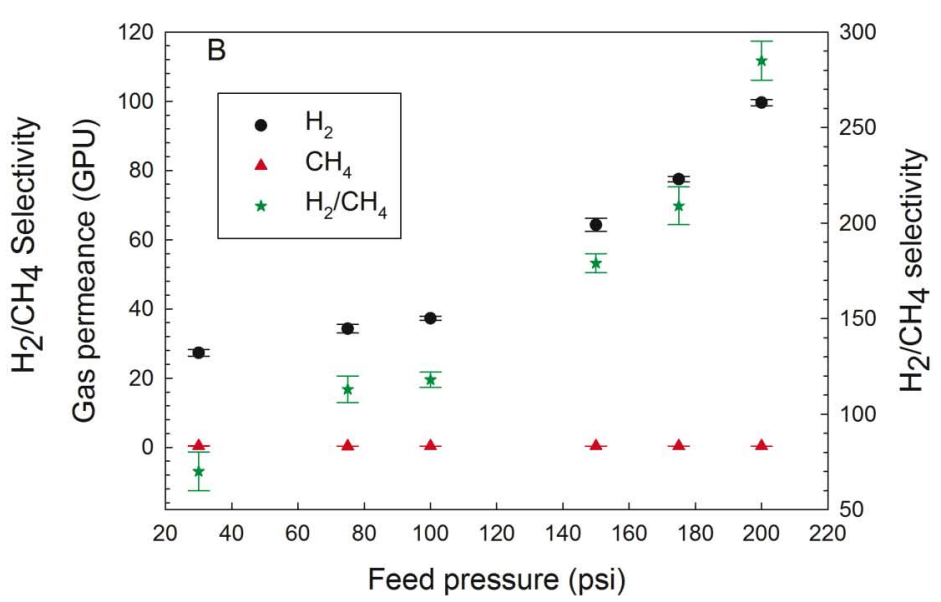

Figure 8: Gas permeation properties of $\mathrm{U} 304$ as a function of: $\mathbf{A})$ temperature $(75 \mathrm{psi})$ and $\mathbf{B})$ pressure $\left(30^{\circ} \mathrm{C}\right)$. 
asymmetric hollow fiber membranes. Their permeances were obtained for different gases $\left(\mathrm{H}_{2}\right.$, $\mathrm{CO}_{2}, \mathrm{O}_{2}, \mathrm{~N}_{2}$ and $\mathrm{CH}_{4}$ ) under different conditions (pressure and temperature). The results showed that no single polymer can be universally used whatever the gas separation to be performed. A careful selection must be made based on the type of gas separation to perform and the operating conditions. In our case, based on selectivity values, Ultem performed best for $\mathrm{H}_{2} / \mathrm{N}_{2}$ (117), $\mathrm{H}_{2} / \mathrm{CH}_{4}$ (91.7) and $\mathrm{O}_{2} / \mathrm{N}_{2}$ (8.8) separation, while Matrimid performed better for $\mathrm{CO}_{2} / \mathrm{N}_{2}$ (34.0) and $\mathrm{CO}_{2} / \mathrm{CH}_{4}$ (24.3). However, the $\mathrm{H}_{2}$ (56.4 GPU) and $\mathrm{CO}_{2}$ (17.7 GPU) permeance of Matrimid were higher than Ultem (38.5 and 7.53 GPU for $\mathrm{H}_{2}$ and $\mathrm{CO}_{2}$ ). Nevertheless, these conclusions only apply for the samples produced and under the conditions tested $\left(30^{\circ} \mathrm{C}\right.$ and 2 bar $)$. Permeance values are very important for industrial applications. For example, the typical $\mathrm{O}_{2} / \mathrm{N}_{2}$ separation can be used to compare the performance of each polymer. Our results showed that PES, Matrimid and Ultem have permeance of $8.4,3.9$ and 2.9 GPU, while their selectivity were 8.8, 7.5 and 5.3 , respectively. In this case, PES would be the best material for $\mathrm{O}_{2}$ enrichment. On the other hand, for $\mathrm{CO}_{2} / \mathrm{N}_{2}$ and $\mathrm{CO}_{2} / \mathrm{CH}_{4}$ separation, Matrimid would be the best membrane material due to its higher $\mathrm{CO}_{2}$ permeance. For $\mathrm{H}_{2} / \mathrm{CH}_{4}$ and $\mathrm{H}_{2} / \mathrm{N}_{2}$ separations, Ultem and Matrimid would be both good materials, while Ultem would perform better for $\mathrm{H}_{2} / \mathrm{CO}_{2}$ due to its high selectivity (5.1) compared to Matrimid (3.2) and PES (2.0). Finally, different results might be obtained for other conditions and this is currently being investigated.

\section{ACKNOWLEDGEMENTS}

The authors would like to thank the Natural Science and Engineering Research Council of Canada (NSERC) for financial support through a strategic grant. $X . Y$. Chen also thanks the Mitacs Acceleration program for a postdoctoral scholarship.

\section{REFERENCES}

[1] Koros WJ, Fleming GK. Membrane-based gas separation. J Membr Sci 1993; 83: 1-80. https://doi.org/10.1016/0376-7388(93)80013-N

[2] Chen $X Y$, Vinh-Thang $H$, Ramirez $A A$, Rodrigue $D$, Kaliaguine $S$. Membrane gas separation technologies for biogas upgrading. RSC Adv 2015; 5: 24399-448. https://doi.org/10.1039/C5RA00666J

[3] Membrane Separation Market - Global Industry Analysis, Size, Share, Growth, Trends and Forecast, 2013 - 2019. [cited 2016 Oct 8]: Available from: http://www.transparencymarketresearch.com/membrane-separation-market.html

[4] Baker RW. in Advanced membrane technology and applications. Li NN, Fane AG, Winston Ho WS, Matsuura T. John Wiley \& Sons, Inc., New Jersey, 2008; pp. 557-580. https://doi.org/10.1002/9780470276280.ch21
[5]

Basu S, Khan AL, Cano-Odena A, Liu CQ, Vankelecom IFJ. Membrane-based technologies for biogas separations, Chem Soc Rev 2010; 39: 750-68. https://doi.org/10.1039/B817050A

[6] Koros WJ, Pinnau I. Membrane formation for gas separation processes. Paul DR, Yampol'skii YP, Eds., CRC Press: Boca Raton Florida, USA 1994.

[7] Sridhar S, Smitha B, Aminabhavi TM. Separation of carbondioxide from natural gas mixtures through polymer membranes-A Review. Sep Pur Rev 2007; 36: 113-74. https://doi.org/10.1080/15422110601165967

[8] Drioli E, Giorno L. in Comprehensive membrane science and engineering, ITM-CNR, University of Calabria, Rende (CS), Italy: Elsevier Science 2010.

[9] Wang DL, Li K, Teo WK. Polyethersulfone Hollow Fiber Gas Separation Membranes Prepared From NMP/Alcohol Solvent Systems. J Membr Sci 1996; 115: 85-108.

\section{https://doi.org/10.1016/0376-7388(95)00312-6}

[10] Wang DL, Li K, Teo WK. Permeable polyethersulfone hollow fiber gas separation membranes prepared using water as non-solvent additive. J Membr Sci 2000; 176: 147-58. https://doi.org/10.1016/S0376-7388(00)00419-1

[11] Qin JJ, Chung TS. Effects of orientation relaxation and bore fluid chemistry on morphology and performance of polyethersulfone hollow fibers for gas separation. J Membr Sci 2004; 229: 1-9. https://doi.org/10.1016/j.memsci.2003.10.014

[12] Lia Y, Cao C, Chung TS, Pramod KP. Fabrication of duallayer polyethersulfone (PES) hollow fiber membranes with an ultrathin dense-selective layer for gas separation. J Membr Sci 2004; 245: 53-60. https://doi.org/10.1016/j.memsci.2004.08.002

[13] Kapantaidakis GC, Koops GH, Wessling M. Preparation and characterization of gas separation hollow fiber membranes based on polyethersulfone-polyimidemiscible blends. Desalination 2002; 145: 353-57.

https://doi.org/10.1016/S0011-9164(02)00435-6

[14] Kusworo TD, Ismail AF, Mustafa A, Budiyono. Studies of Thermal annealing on Suppression of Plasticization of the Asymmetric Hollow Fiber Mixed Matrix Membranes. World Applied Sciences Journal 2013; 28: 09-19.

[15] Widjojo N, Chung TS, Kulprathipanja S. The fabrication of hollow fiber membranes with double-layer mixed-matrix materials for gas separation. J Membr Sci 2008; 325: 326-35. https://doi.org/10.1016/j.memsci.2008.07.046

[16] Ismail AF, Kusworo TD, Mustafa A. Enhanced gas permeation performance of polyethersulfone mixed matrix hollow fiber membranes using novel Dynasylan Ameo silane agent. J Membr Sci 2008; 319: 306-12. https://doi.org/10.1016/j.memsci.2008.03.067

[17] Chen HZ, Xiao YC, Chung TS. Multi-layer composite hollow fiber membranes derived from poly(ethyleneglycol) (PEG) containing hybrid materials for $\mathrm{CO}_{2} / \mathrm{N}_{2}$ separation. $\mathrm{J}$ Membr Sci 2011; 381: 211-220. https://doi.org/10.1016/j.memsci.2011.07.023

[18] Wang DL, Li K, Teo WK. Preparation and characterization of polyetherimide asymmetric hollow fiber for gas separation. J Membr Sci 1998; 138: 193-201 https://doi.org/10.1016/S0376-7388(97)00229-9

[19] Husain S, Koros WJ. Mixed matrix hollow fiber membranes made with modified HSSZ-13, zeolite in polyetherimide polymer matrix for gas separation. J Membr Sci 2007; 288 : 195-207. https://doi.org/10.1016/j.memsci.2006.11.016

[20] Dai Y, Johnson JR, Karvan O, Sholl DS, Koros WJ. Ultem ${ }^{\circledR} / Z I F-8$ mixed matrix hollow fiber membranes for $\mathrm{CO}_{2} / \mathrm{N}_{2}$ separations. J Membr Sci 2012; 401-402: 76-82. https://doi.org/10.1016/j.memsci.2012.01.044 
[21] Shieh JJ, Chung TS, Wang R, Srinivasan MP, Paul DR. Gas separation performance of poly(4-vinylpyridine)/ polyetherimide composite hollow fibers. J Membr Sci 2001; 182: 111-23.

https://doi.org/10.1016/S0376-7388(00)00560-3

[22] Peng N, Chung TS, Chng ML, Aw WQ. Evolution of ultra-thin dense-selective layer from single-layer to dual-layer hollow fibers using novel Extem $®$ polyetherimide for gas separation. J Membr Sci 2010; 360: 48-57.

https://doi.org/10.1016/j.memsci.2010.04.046

[23] Clausi DT, Koros WJ. Formation of defect-free polyimide hollow fiber membranes for gas separations. J Membr Sci 2000; 167: 79-89.

https://doi.org/10.1016/S0376-7388(99)00276-8

[24] Krol JJ, Boerrigter M, Koops GH. Polyimide hollow fiber gas separation membranes: preparation and the suppression of plasticization in propane/propylene environments. J Membr Sci 2001; 184: 275-86.

\section{https://doi.org/10.1016/S0376-7388(00)00640-2}

[25] Kapantaidakis GC, Koops GH, Wessling M. Preparation and characterization of gas separation hollow fiber membranes based on polyethersulfone-polyimide miscible blends. Desalination 2002; 145: 353-57.

https://doi.org/10.1016/S0011-9164(02)00435-6

[26] Hosseini SS, Teoh MM, Chung TS. Hydrogen separation and purification in membranes of miscible polymer blends with interpenetration networks. Polymer 2008; 49: 1594-603. https://doi.org/10.1016/j.polymer.2008.01.052

[27] Yong WF, Li FY, Xiao YC, Chung TS, Tong YW. High performance PIM-1/Matrimid hollow fiber membranes for $\mathrm{CO}_{2} / \mathrm{CH}_{4}, \mathrm{O}_{2} / \mathrm{N}_{2}$ and $\mathrm{CO}_{2} / \mathrm{N}_{2}$ separation. J Membr Sci 2013; 443: $156-169$.

https://doi.org/10.1016/j.memsci.2013.04.037

[28] Li DF, Chung TS, Wang R. Morphological aspects and structure control of dual-layer asymmetrichollow fiber membranes formed by a simultaneous co-extrusion approach. J Membr Sci 2004; 243: 155-75.

https://doi.org/10.1016/j.memsci.2004.06.014

[29] Jiang LY, Chung TS, Li DF, Cao C. Kulprathipanja S, Fabrication of Matrimid/polyethersulfone dual-layer hollow fiber membranes for gas separation. J Membr Sci 2004; 240: 91-103.

https://doi.org/10.1016/j.memsci.2004.04.015

[30] Hosseini SS, Peng N, Chung TS. Gas separation membranes developed through integration of polymer blendingand dual-layer hollow fiber spinning process for hydrogen and natural gas enrichments. J Membr Sci 2010; 349: 156-166.

https://doi.org/10.1016/j.memsci.2009.11.043

[31] Dong GX, Li HY, Chen V. Factors affect defect-free Matrimid $\AA$ hollow fiber gas separation performance in natural gas purification. J Membr Sci 2010; 353: 17-27. https://doi.org/10.1016/j.memsci.2010.02.012

[32] Hu T, Dong GX, Li HY, Chen V. Effect of PEG and PEOPDMS copolymer additives on the structure and performance of Matrimids hollow fibers for CO2 separation. J Membr Sci 2014; 468: 107-17.

https://doi.org/10.1016/j.memsci.2014.05.024
[33] Liu L, Sanders ES, Johnson JR, Karvan O, Kulkarni S, Hasse DJ, Koros WJ. Influence of membrane skin morphology on $\mathrm{CO}_{2} / \mathrm{N}_{2}$ separation at sub- ambient temperatures. J Membr Sci 2013; 446: 433-39.

https://doi.org/10.1016/j.memsci.2013.06.001

[34] von Wroblewski S. Under absorption of gas. Theor Appl 1879; 8: 418-19.

[35] Pesek SC, Koros WJ. Aqueous quenched asymmetric polysulfone hollow fibers prepared by dry/wet phase separation. J Membr Sci 1994; 88: 1-19. https://doi.org/10.1016/0376-7388(93)E0150-I

[36] Wang L, Cao YM, Zhou MQ, Zhou SJ, Yuan Q. Novel copolyimide membranes for gas separation. J Membr Sci 2007; 305: 338-46.

https://doi.org/10.1016/j.memsci.2007.08.024

[37] Chen XY, Rodrigue D, Kaliaguine S. Diamino-organosilicone APTMDS: A new cross- linking agent for polyimides membranes. Sep Pur Techn 2012; 86: 221-33. https://doi.org/10.1016/j.seppur.2011.11.008

[38] Bakeri GH, Ismail AF, Rahimnejad M, Matsuura T, Rana D. The effect of bore fluid type on the structure and performance of polyetherimide hollow fiber membrane in gas-liquid contacting processes. Sep Pur Techn 2012; 98: 262-69. https://doi.org/10.1016/j.seppur.2012.07.024

[39] Chen XY, Kaliaguine S. Mixed Gas and Pure Gas Transport Properties ofCopolyimide Membranes. J Appl Polym Sci 2013; 28: 380-89. https://doi.org/10.1002/app.37728

[40] Ma CH, Zhang C, Labreche Y, Fu SL, Liu L, Koros WJ. Thinskinned intrinsically defect-free asymmetric mono-esterified hollow fiber precursors for crosslinkable polyimide gas separation membranes. J Membr Sci 2015; 493: 252-62. https://doi.org/10.1016/j.memsci.2015.06.018

[41] Kesting RE. Synthetic Polymeric Membranes, second ed., Wiley, New York 1985.

[42] Bakeri GH, Ismail AF, Rezaei M, Arzhandi D, Matsuura T. Porous PES and PEI hollow fiber membranes in a gas-liquid contacting process-A comparative study. J Membr Sci 2015; 475: 57-64.

https://doi.org/10.1016/j.memsci.2014.09.037

[43] Caminoa G, Lomakin SM, Lazzaria M. Polydimethylsiloxane thermal degradation Part 1. Kinetic aspects. Polymer 2001; 42: $2395-402$. https://doi.org/10.1016/S0032-3861(00)00652-2

[44] Chung TS, Xu ZL, Lin WH. Fundamental Understanding of the Effect of Air-Gap Distance on the Fabrication of Hollow Fiber Membranes. J Appl Polym Sci 1999; 72: 379-95. https://doi.org/10.1002/(SICl)10974628(19990418)72:3<379::AID-APP8>3.0.CO;2-B

[45] $\mathrm{Ma} \mathrm{CH}$. Optimization of asymmetric hollow fiber membranes for natural gas separation, Georgia Institute of Technology, USA 2011.

[46] Ismaila AF, Dunkinb IR, Gallivanb SL, Shilton SJ. Production of super selective polysulfone hollow fiber membranes for gas separation. Polymer 1999; 40: 6499-06. https://doi.org/10.1016/S0032-3861(98)00862-3

Received on 01-02-2017

Accepted on 23-02-2017

Published on 07-04-2017

DOI: https://doi.org/10.6000/1929-6037.2017.06.01.1

(C) 2017 Chen et al.; Licensee Lifescience Global.

This is an open access article licensed under the terms of the Creative Commons Attribution Non-Commercial License (http://creativecommons.org/licenses/by-nc/3.0/) which permits unrestricted, non-commercial use, distribution and reproduction in any medium, provided the work is properly cited. 